\title{
Mobile Application Design for Student Learning
}

\author{
Angelina, Weliati, Edwin Christian Jonatan Wardoyo, Sugiarto Hartono* \\ Information Systems Department, School of Information Systems, Bina Nusantara University, Jakarta, Indonesia 11480
}

\begin{tabular}{l} 
A R T I C L E I N F O \\
\hline Article history: \\
Received: 07 October, 2020 \\
Accepted: 16 January, 2021 \\
Online: 05 February, 2021 \\
\hline Keywords: \\
Mobile Application \\
Online Learning \\
Assignment \\
Report \\
OOAD \\
\hline
\end{tabular}

\section{Introduction}

PT. Ruang Raya Indonesia is a startup company engaged in educational technology. According to [1], the development of information and communication technology allows humans to exchange information in a short time without being limited by distance and time. As a result of globalization, there is free competition in the world of work, trade, and education. Advances in information and communication technology, especially in the field of education, have implications for how to use information and communication technology in the learning and teaching process as attractive as possible as a source of learning and improve the quality of education. Agreeing with Junaedi, [2] also argue that smartphones can be used for learning media, and one of the operating systems that can be run by smartphones is android. According to [3] smartphones have the impact of portability, namely practical and can be used to study anywhere and anytime.

According to [4], sometimes even though school teachers have taught well, students have the possibility of not understanding the material presented at school, so that additional material through tutoring may be needed by students to help students understand the material. In [5], the author revealed that private tutoring improves students' understanding of the subject matter, and has slightly better academic achievement than students who do not do private lessons.

*Corresponding Author: Sugiarto Hartono, shartono@binus.ac.id
Based on the percentage of APJII regarding the sector of internet service users, when viewed from the employment sector, the majority of the internet in Indonesia is used in the trade and service sector than in the $3 \mathrm{rd}$ place in education. The estimated increase in the number of smartphone users in Indonesia according to data quoted from [6] can reach 108 million users, taking into account this and also the opinions of users, all of these features will be developed on smartphones with the Android operating system. With this application, PT. Ruang Raya Indonesia has the hope of increasing student's interest in learning anywhere and anytime.

According to [7], there are 10 components that can be considered for an LMS, 2 of which are content development aimed at helping and also motivating students to learn, in this case, the teacher must be able to upload the teacher's notes. but the teacher also has to upload supporting material to increase student knowledge of certain materials. Apart from that students must be able to obtain supporting material, teachers must also be able to monitor student participation and development. The LMS must be able to record whether students take part in discussions or submit assignments.

Based on the results of data collection regarding the needs of users and stakeholders of the application at this time, it is found that the problems are both less supportive applications and lack of features to make users receive more information. Where current technology students feel uncomfortable with the current website because the page display is in the form of letters that can be very small and can be very large, writing that can overlap with other 
writing and the layout of images that are not suitable so that it blocks other writing or images. The results of private lessons are not supported by documentation that can be seen directly by students. This results in a student not being able to know his academic progress while taking private lessons. The right place for doing assignments for students to do assignments given by private tutors. This allows students who take private lessons not to get enough enrichment assignments to improve students' academic abilities on the material taken. Then the private tutoring schedule that cannot be changed based on the situation at that time.

Seeing from all existing aspects, the application that is owned by PT. Ruang Raya can now be developed better to meet the needs of users. then it is proposed to do development that includes things such as acting classes, class history, online private tutor assignments, making student academic progress reports, making questions for student assignments, changing private teacher schedules.

The application developed aims to allow students to see a list of classes being taken by students and a list of classes that have been taken, allowing students to see the initial class plans taken and to view reports on academic progress during class, allowing students to change private tutoring schedules due to unpredictable obstacles, and allows students to do assignments given by private tutors and be able to see the value and discussion of this paper.

\section{Research Method}

In obtaining the data and information needed in this application design analysis, several methods are used as follows:

\subsection{Data collection methodology}

- $\quad$ Literature Review

Doing a literature study by looking at references from several books related to problems related to the problem, as well as looking for other references from the internet.

\section{- Field Study}

The first step will be observed. Where this observation is for data collection by observing directly about running business processes such as usage, and daily problems that occur with company applications.

The second step is to conduct interviews by holding direct questions and answers with related parties to obtain an overview of the ongoing business processes.

Then the third step is a questionnaire. This questionnaire was conducted using online distribution. Where the sample size taken is based on the Slovin formula. This questionnaire is distributed to students to obtain an overview of problems for the running system, to obtain student opinions on the application being developed, and to obtain information on the required features. Questions will be made open-ended and closed-ended questions, where closed questions are made and processed based on a Likert scale, that is, with questions measuring students' agreement and disagreement with a subject and have been arranged based on the need to obtain the required data and information.

\subsection{Methods of Analysis and Application Design}

The method used to develop applications is the ObjectOriented Analysis and Design (OOAD) method. The design stages are as follows:

Inception Phase

In this phase, determine the scope of the system to be designed and identify the system requirements. The focus in this stage is as follows:

- Identification and Analysis of Company and User Needs

- Observation of business processes and running applications

- Analyze the results of the questionnaire

- Determination of problems with the system and running application

- Recommended solutions on running systems and applications

All requirements obtained will be documented in the UML diagram as follows:

- Activity Diagram

- Use Case Diagram

- Domain Class Diagram

- Use Case Description

- State Machine Diagram

\subsection{Elaboration Phase}

In this phase, analysis and design of the system architecture is carried out, analysis of the system requirements is carried out in more depth and ensures that all user needs are identified. Documentation for Use Case Realization will be documented in the UML diagram used at this stage:

- User Interface

- Multilayer System Sequence Diagram

- Update Design Model Class Diagram

- Package Diagram

\section{Result And Discussion}

\subsection{User Needs Analysis}

Based on the user needs that have been obtained from the data collection process through questionnaires and interviews, it can be concluded that the needs of students who have not been met in the application are as follows:

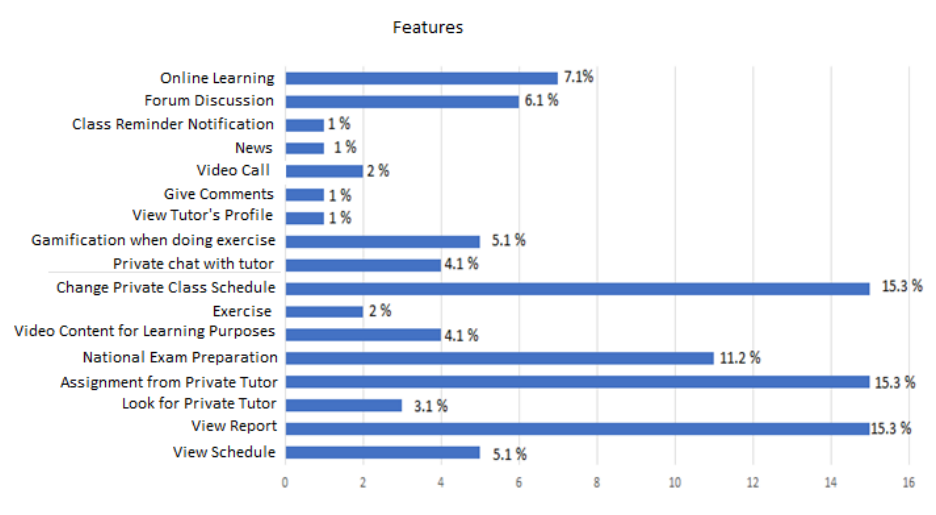

Figure 1: Graphics of desirability of features in smartphones

Judging from the level of user needs, the features that are needed by users who are in the top three are doing assignments, 
changing schedules, and viewing academic reports with a percentage of $15.3 \%$. By looking at these priorities, these features are the top priority for the design to be made in advance to meet the needs of the user.

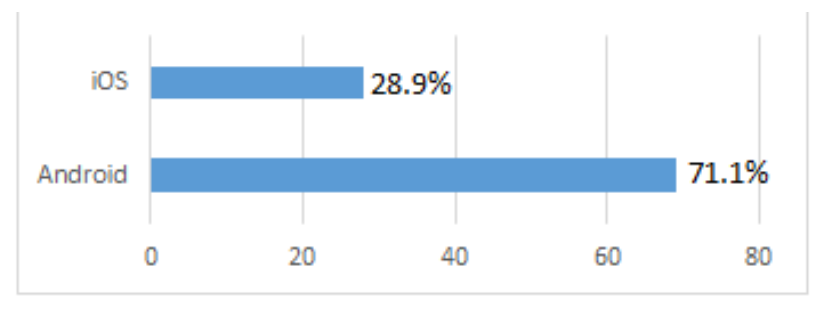

Figure 2: Graph of the operating system requirements on a smartphone

The development plan is made on the Android operating system because it sees the needs of the most selected users with a percentage of $71.1 \%$ so that development on the Android operating system becomes a development priority.

\subsection{Problem Analysis}

The problems faced in the current business process are as follows:

- Students who have taken private lessons can only be accessed on the official website where things that can be accessed are a list of active classes along with their details and class history. However, students feel uncomfortable with the current website because the appearance of the page is in the form of letters that can be very small and can be very large, the writing can overlap with other writing, and the layout of the images is not suitable so that it blocks other writing or images.

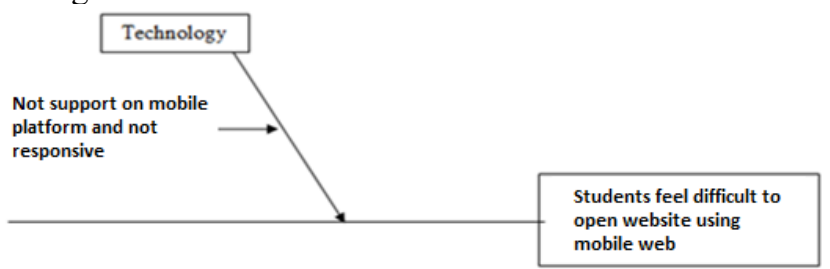

Figure 3: Fishbone Problem 1

- Currently, the results of private lessons are not supported by documentation that can be seen directly by students. This results in a student not being able to know his academic progress while taking private lessons.

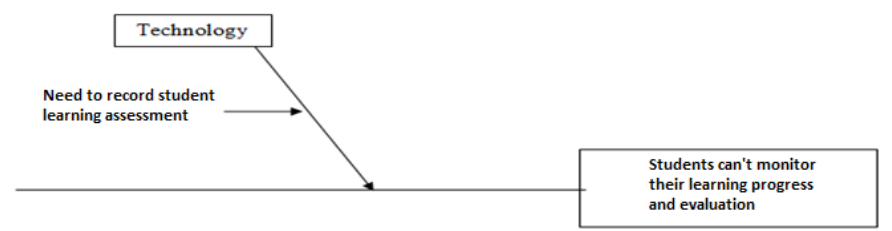

Figure 4: Fishbone Problem 2

- There is no proper place for performing assignments for students to do assignments given from private tutors. This allows students who take private lessons not to get enough enrichment assignments to improve students' academic abilities on the material taken. Where time is limited and

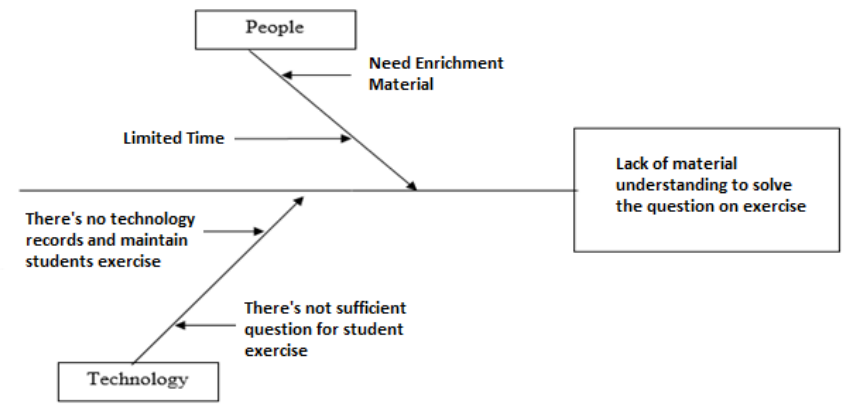

Figure 5: Fishbone Problem 3

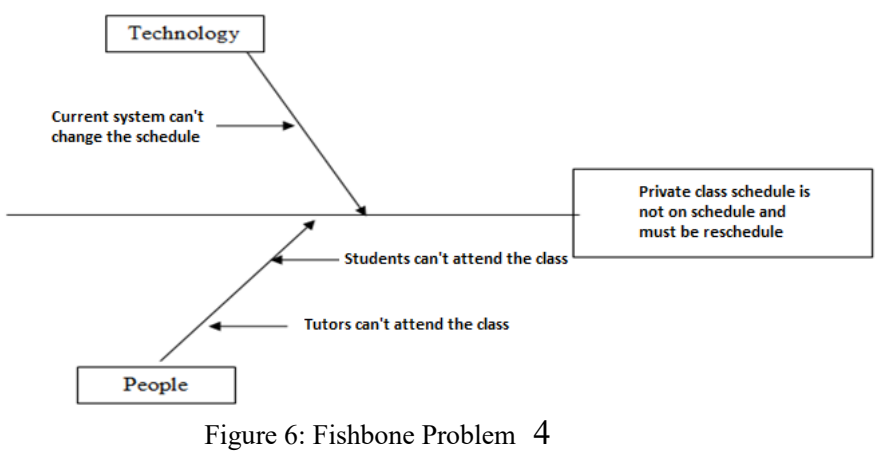

4. Solutions

Proposals on Problems faced by PT. Ruang Raya Indonesia is as follows:

Table 1: Problem 1

\begin{tabular}{|l|l|}
\hline Problem & $\begin{array}{l}\text { Students who have taken private } \\
\text { lessons can only be accessed on the } \\
\text { official website. However, the page } \\
\text { display is in the form of letters that can } \\
\text { be very small and can be very large, text } \\
\text { that can overlap with other writing, and } \\
\text { the layout of the Figure is not suitable } \\
\text { so that it blocks other text or figures. }\end{array}$ \\
\hline Solution & $\begin{array}{l}\text { Designed and built on mobile for this } \\
\text { feature so students will be able to see } \\
\text { the list by simply logging into the active } \\
\text { class. }\end{array}$ \\
\hline Reference & $\begin{array}{l}\text { According to [5]: Strive for } \\
\text { consistency, shortcuts to universal } \\
\text { usability, offer informative feedback, } \\
\text { design dialogue to generate closings, } \\
\text { prevent errors, easy to reverse actions, } \\
\text { support the internal focus of control, } \\
\text { reduce short-term memory load }\end{array}$ \\
\hline Features & $\begin{array}{l}\text { - Students can see active Class } \\
\text { - Students can view class history }\end{array}$ \\
\hline
\end{tabular}


Table 2: Problem 2

\begin{tabular}{|l|l|}
\hline Problem & $\begin{array}{l}\text { The results of private lessons are not } \\
\text { supported by documentation that can be } \\
\text { seen directly by students }\end{array}$ \\
\hline Solution & $\begin{array}{l}\text { Designed and made features to see } \\
\text { student academic progress. This feature } \\
\text { will be a place for students to see how } \\
\text { their abilities are during class. }\end{array}$ \\
\hline Reference & $\begin{array}{l}\text { According to [5], all evaluation results } \\
\text { must be reported to various interested } \\
\text { parties, parents/guardians, school } \\
\text { principals, supervisors, government, } \\
\text { school partners, and the students } \\
\text { themselves. This intended so that the } \\
\text { learning process, including the learning } \\
\text { process and outcomes achieved by } \\
\text { students and its development, can be } \\
\text { known by various parties. The report on } \\
\text { student learning progress is a means of } \\
\text { communication between schools, } \\
\text { students, and parents to develop and } \\
\text { maintain a harmonious cooperative } \\
\text { relationship between them. Broadly } \\
\text { speaking, the purpose of reporting } \\
\text { student learning outcomes is to provide } \\
\text { accurate, clear information about the } \\
\text { progress of student learning outcomes } \\
\text { within a certain period, providing } \\
\text { feedback for a student in knowing the } \\
\text { strengths and weaknesses that give rise } \\
\text { to motivation for learning outcomes, } \\
\text { determine the progress of individual } \\
\text { student learning outcomes in achieving } \\
\text { competence. }\end{array}$ \\
\hline Features & $\begin{array}{l}\text { Students can view academic progress } \\
\text { reports which consist of initial } \\
\text { documentation reports, evaluation of } \\
\text { sessions, evaluation reports }\end{array}$ \\
\hline
\end{tabular}

Table 3: Problem 3

\begin{tabular}{|l|l|}
\hline Problem & $\begin{array}{l}\text { Schedule that cannot be adjusted based } \\
\text { on the conditions that occur }\end{array}$ \\
\hline Solution & $\begin{array}{l}\text { The features proposed are features of } \\
\text { private tutoring schedule changes. This } \\
\text { feature allows students or teachers to } \\
\text { make changes to the private tutoring } \\
\text { schedule that has been agreed upon in } \\
\text { advance with the agreement of the two } \\
\text { parties concerned. This feature is } \\
\text { expected to help students or teachers to } \\
\text { rearrange their private tutoring } \\
\text { schedules so that private tutoring } \\
\text { learning activities can run smoothly. }\end{array}$ \\
\hline Reference & $\begin{array}{l}\text { According to [5] states that "a schedule } \\
\text { is defined as something that describes }\end{array}$ \\
\hline
\end{tabular}

\begin{tabular}{|l|l|}
\hline & $\begin{array}{l}\text { where and when people and resources } \\
\text { are at a time. Based on the Big } \\
\text { Indonesian Dictionary, the schedule is } \\
\text { the division of time-based on the work } \\
\text { order arrangement plan. " Most people } \\
\text { are familiar with lesson schedules } \\
\text { presented as a table of days of the week } \\
\text { and timeframes. It can be seen that each } \\
\text { day is divided into periods. Each term } \\
\text { has a list of courses being taught, by } \\
\text { whom, and where. Schedules can be } \\
\text { stated in several different ways, each } \\
\text { student must have their schedule } \\
\text { depending on the subject, as well as } \\
\text { each teacher and room, all of these are } \\
\text { different perspectives on the same } \\
\text { schedule }\end{array}$ \\
\hline Features & \begin{tabular}{l} 
Student can reschedule \\
\hline
\end{tabular} \\
\hline
\end{tabular}

1. Application Design Result

- Use Case Diagram

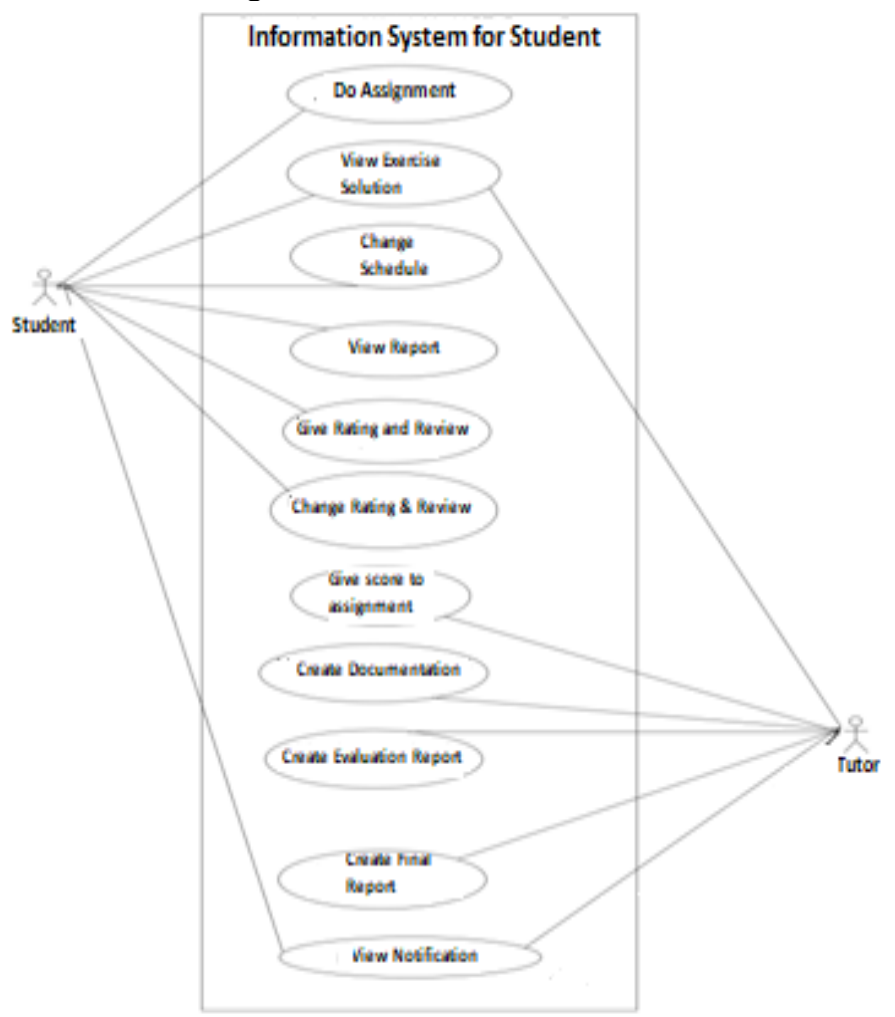

Figure 7: Use Case Diagram

Activities that will be carried out in the application that are designed are doing assignments, viewing discussions - working on assignments, changing schedules, viewing reports, making reviews and ratings, changing reviews and ratings, viewing notifications (students), viewing discussions - active class (students), and see the discussion - history of class (students) where this activity will be carried out by students. Then make assignments, make initial documentation, make evaluation sessions, make evaluation reports, view notifications (teachers), see discussions (teachers), and decide on changes to private 
tutoring schedules where this activity is carried out by the teacher. Furthermore, changing the initial documentation, changing the evaluation session, creating evaluation reports, changing assignments, and deleting tasks where this activity is carried out by the admin.

- Domain Class Diagram

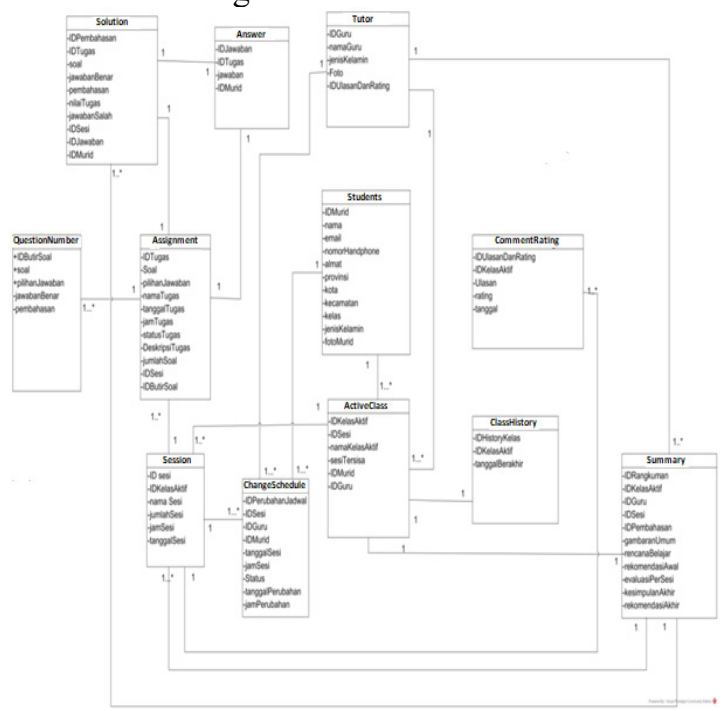

Figure 8: Domain Class Diagram

- User Interface
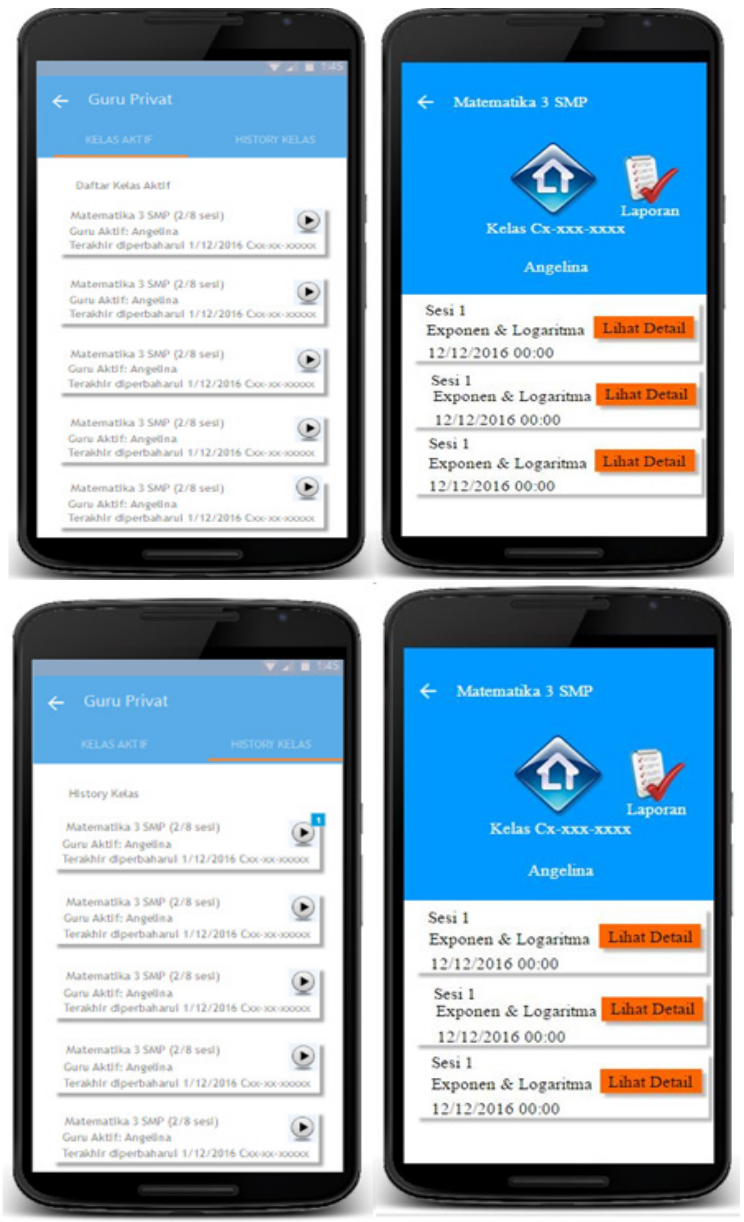

Figure 9: Active Class Look-Class history
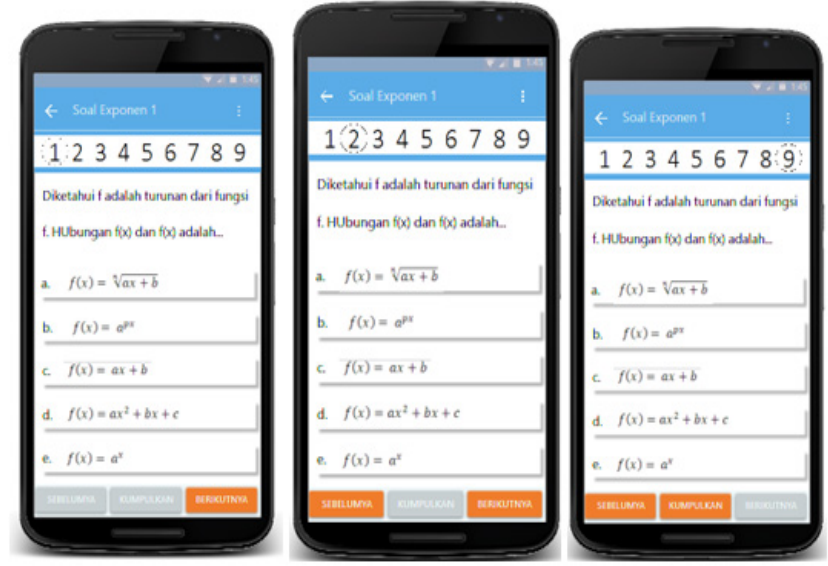

Figure 10: Doing task

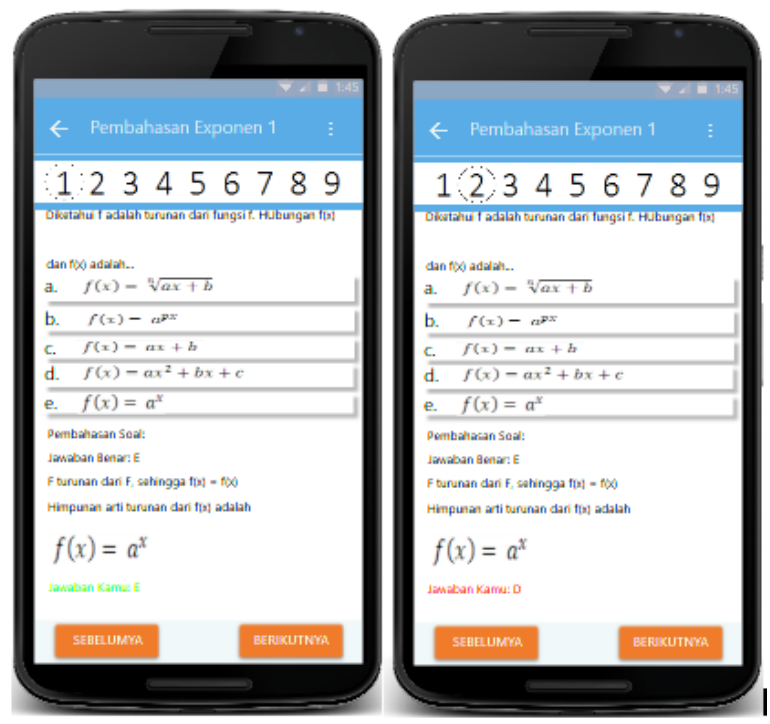

Figure 11: Discussion

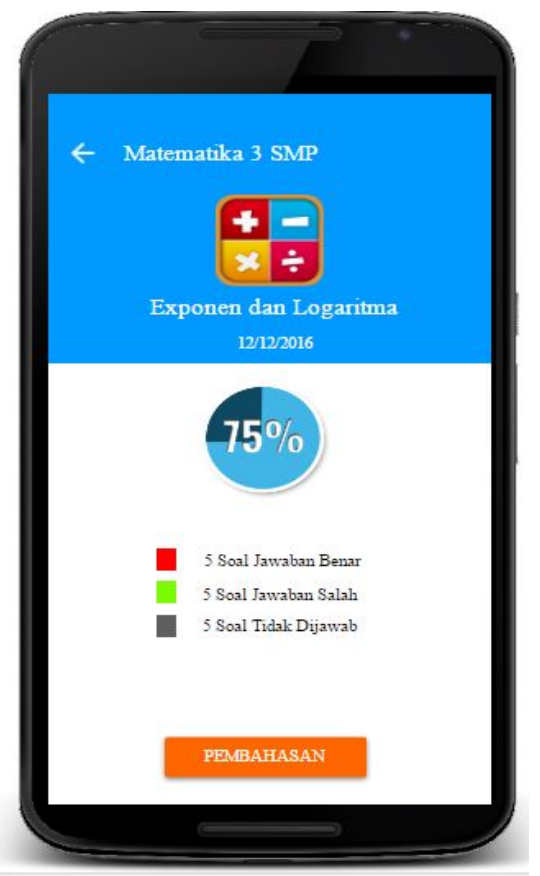

Figure 12: Result of Task 

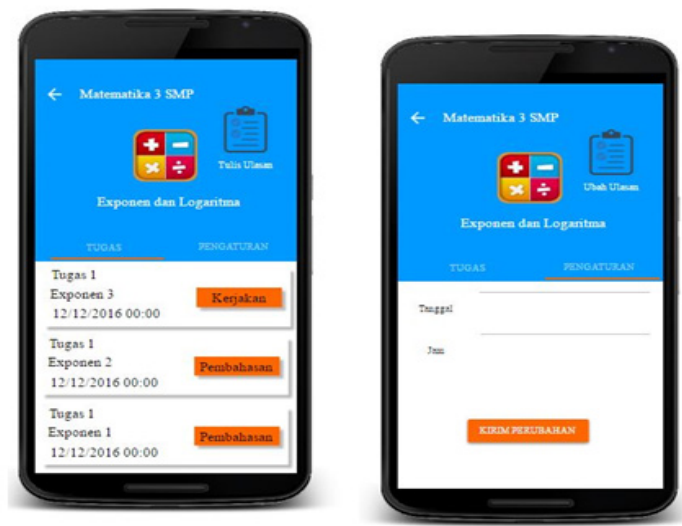

Figure 13: Reschedule
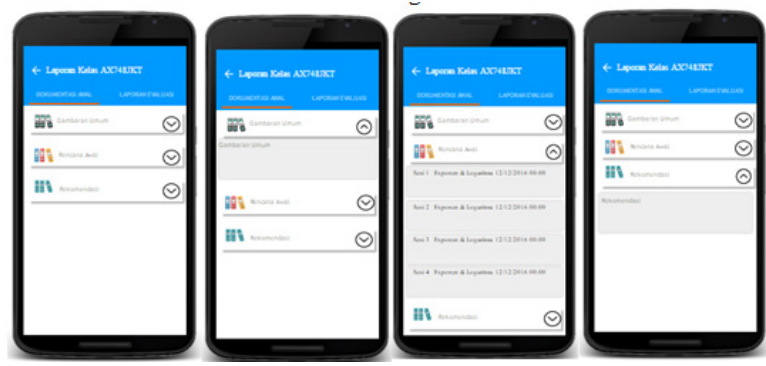

Figure 14: Report View
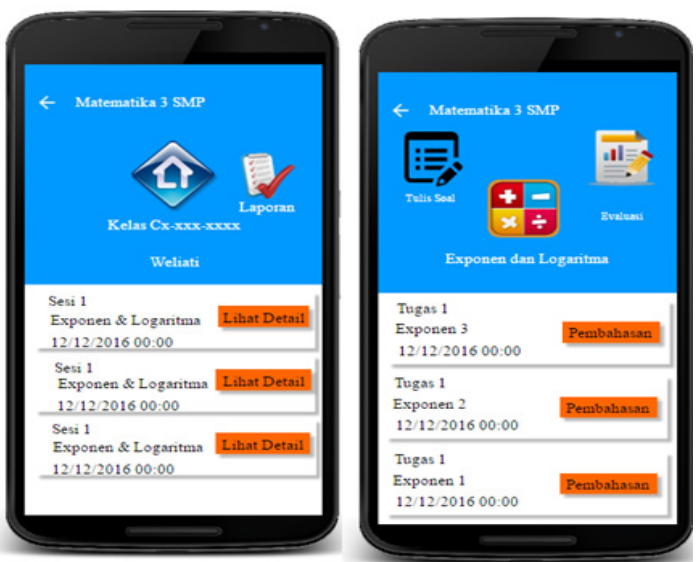

Figure 15: Making report-teacher

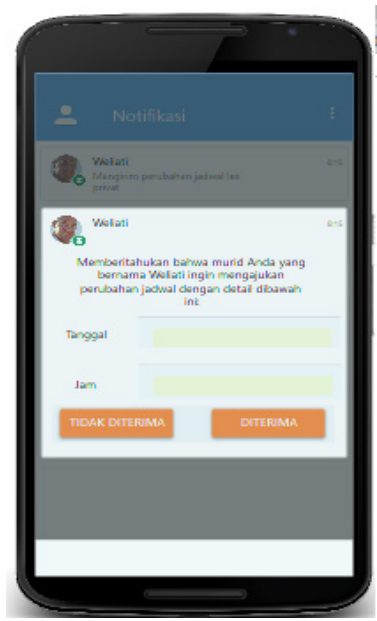

Figure 16: The view prompts for approval of a schedule change request
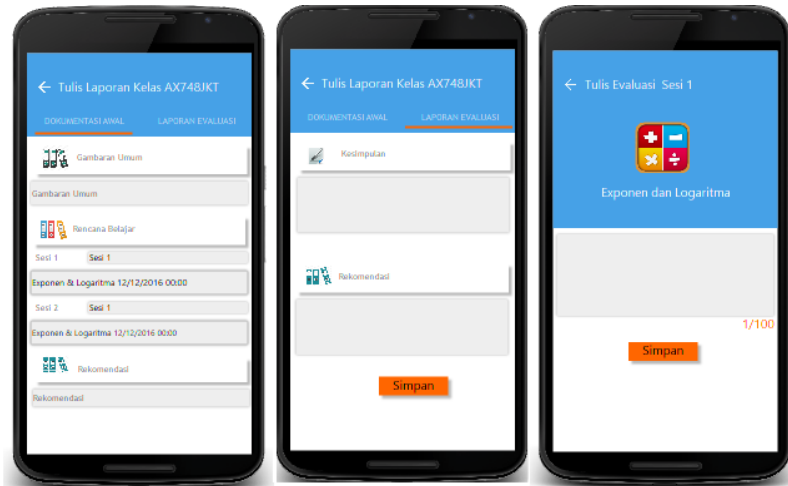

Figure 17: Making report-teacher

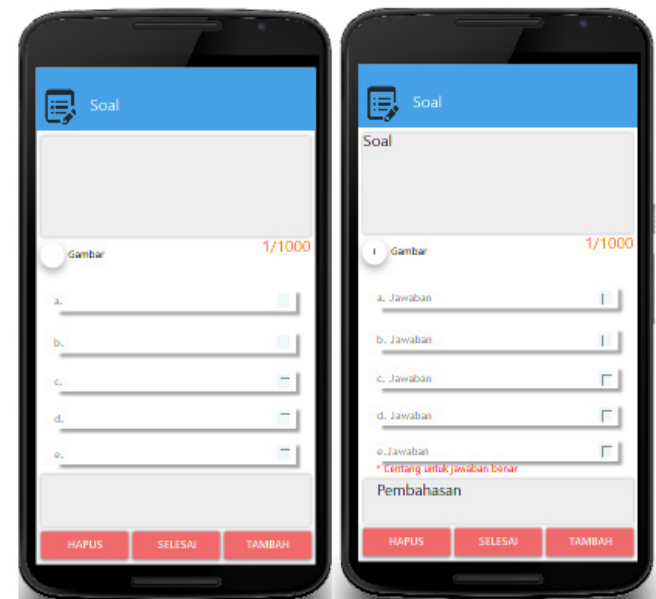

Figure 18: Making queestions-teacher

\section{Conclusion}

After analyzing the student application at PT Ruang Raya Indonesia, the following conclusions are obtained:

- PT. Ruang Raya Indonesia is a company that develops products and services in the field of educational technology. One of them is a mobile-based application with online chat features and can communicate and can ask questions that are not understood. However, the existing features still do not support students to interact more with mobile applications because there are very limited things students can do. With application development carried out, students will be able to interact more because students can see active classes taken, history of active classes that have been taken, work on assignments for student training, discussion of assignments that have been done, can change schedules, and can view reports - progress reports during private lessons.

- In the current running system, there are only a few features and features that do not meet user needs. As found there were no reports that could show the progress of students while taking private lessons. So it is proposed a development plan to view reports on academic progress. The report is filled in by private teachers in a special mobile-based application for teachers. In the teacher application, features are added to view the active class, make reports, make assignments, and make discussions which are used by the teacher as a basis for providing evaluation reports. 
Based on the results of student application research at PT. Ruang Raya Indonesia, the advice that can be given to PT. Ruang Raya Indonesia is:

- To build an application design that has been made by PT. Ruang Raya Indonesia requires human resources who understand the use of Android Studio software.

- Make the features of the National Examination Practice Questions or tryouts so that students who need practice questions can carry out learning independently by working on questions from the question bank provided to prepare for future exams.

- Create a discussion forum so that students can have a community in the student application and can study groups online to explore existing material. With this forum students can also interact with each other with other students so that students who still have questions about a material can be assisted by other students in doing practice questions, learning modules and so on.

- Developing the search for private tutors because of the features to select and negotiate with the teacher directly regarding the teaching time schedule, and also the price per session for the total cost of teaching private tutors with students according to the existing private tutor ordering procedure.

- Make a learning video which contains a discussion of the material along with an explanation that students can understand. This video is useful for students to better understand the material by explaining it directly through the video.

\section{References}

[1] E. Junaedi, Pengaruh Modul Elektronik Berbasis Mobile Learning Terhadap Peningkatan Hasil Belajar Siswa Pada Mata Pelajaran Teknologi Informasi Dan Komunikasi, Universitas Pendidikan Indonesia, 2013.

[2] E. Supriyono, Heru., Saputra, Ardhiyatama Nur., Darsono, Ruswa., Sudarmilah, Rancang Bangun Aplikasi Pembelajaran Hadis Untuk Perangkat Mobile Berbasis Android, Universitas Muhammadiyah, Surakarta, 2014

[3] D.P. Barakati, Dampak Pengguna Smartphone Dalam Pembelajaran Bahasa Inggris (Persepsi Mahasiswa), Universitas Sam Ratulangi, Manado, 2013.

[4] D.R. Das, Gunendra Chandra., Das, : ., Assam, 2013.

[5] J. Wittwer, "Discussion: Conditions, processes, and effects of private tutoring," Journal for Educational Research Online, 6, 125, 2014

[6] Indonesia, Raksasa Teknologi Digital Asia, 2015.

[7] B.A. Lewis et al., "Learning Management System Comparison," Proceedings of the 2005 Informing Science and IT Education Joint Conference, 18-25, 2005. 